\title{
KORELASI PARSIAL ANTARA HARGA SEWA DAN NILAI KONFIGURASI RUANG PADA PASAR TRADISIONAL BINTAN CENTER
}

\author{
$\underline{\text { Andi }}^{1}$, Muhammad Alif Khairil Akbar ${ }^{2}$, Bontor Jumaylinda Gultom ${ }^{3}$ \\ ${ }^{1}$ Center of Southeast Asian Ethnicities, Cultures and Societies, \\ Pontianak \\ ${ }^{2}$ Mahasiswa Sarjana-1, Program Studi Arsitektur, Fakultas Teknik, \\ Universitas Tanjungpura, Pontianak \\ 3 Dosen Program Studi Arsitektur, Fakultas Teknik, \\ Universitas Tanjungpura, Pontianak \\ Email korespondensi : andizhangnd@gmail.com
}

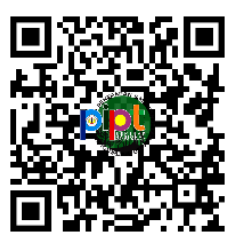

10.26418/pipt.2021.13

\begin{abstract}
Abstrak
Pasar tradisional adalah suatu ruang transaksi antara penjual dan pembeli yang umumnya tersusun dengan konfigurasi blok-blok atau barisan toko yang menghadap ke arah sirkulasi. Penelitian terdahulu menemukan adanya hubungan antara konfigurasi ruang dan profit. Penelitian ini bertujuan melihat hubungan antara konfigurasi ruang dan harga sewa dengan menggunakan korelasi parsial. Penelitian ini menggunakan data konfigurasi ruang dan data harga sewa dari Pasar Tradisional Bintan Center. Data konfigurasi ruang diperoleh dengan analisis spasial menggunakan metode space syntax. Dalam space syntax, data konfigurasi ruang dibagi menjadi nilai pencapaian ruang (nilai integration) dan nilai kedalaman ruang (nilai step depth). Data harga sewa toko diperoleh dari pengelola pasar. Hasil dari penelitian ini adalah ditemukannya korelasi rendah antara konfigurasi ruang dan harga sewa di Pasar Tradisional Bintan Center. Koefisien korelasi antara pencapaian ruang (nilai integration) dan harga sewa adalah $-9,65 \%$, sedangkan koefisien korelasi antara kedalaman ruang (nilai step depth) dan harga sewa adalah 7,412\%. Kedua koefisien ini tergolong sangat rendah (1\% sampai dengan 20\%). Kedua nilai konfigurasi ruang ini memberi hubungan yang berbeda dan kontradiktif dimana satu negatif dan yang satu positif. Berdasarkan koefisien ini yang mendekat 0 ini, dapat disimpulkan tidak ada korelasi yang signifikan antara konfigurasi ruang dan harga sewa di Pasar Tradisional Bintan Center. Adanya muncul nilai korelasi sangat rendah ini dapat dilihat sebagai suatu bentuk kebetulan. Tidak adanya korelasi konfigurasi ruang dan harga sewa merupakan indikator ketidaksesuaian sistem dalam menentukan harga sewa. Pengelola pasar perlu mengevaluasi kembali ketetapan harga sewanya berdasarkan konfigurasi ruang agar terwujud kesejahteraan penjual di pasar tradisional.
\end{abstract}

Kata kunci: Pasar tradisional, Space syntax, konfigurasi ruang, harga sewa, korelasi parsial

\section{PENDAHULUAN}

Pasar tradisional adalah tempat diperjualbelikannya bahan pokok kebutuhan sehari-hari seperti sayur, daging, buah, bumbu-bumbu dapur, pakaian, dan barangbarang sekunder (Halim \& Herlambang, 2020). Kegiatan perdagangan di pasar memiliki nilai sosial yang terlihat dari kegiatan tawar menawar harga barang. Para penjual bertindak sebagai agen penentu harga barangnya (Syarifuddin, 2018). Di Indonesia, pasar tradisional atau pasar rakyat menjadi tempat pusat kegiatan sosial dan ekonomi dari sebuah permukiman dan kota (Aliyah,
2020). Pasar tradisional dikelola oleh suatu badan usaha perorangan ataupun sekelompok orang yang dapat berupa pemerintah, atau swasta (Sarwoko, 2008). Pasar ini menjadi prasarana bagi kegiatan usaha dengan modal kecil yang dijalankan oleh individu, rumah tangga, usaha mikro, kecil dan menengah (UMKM) (Tambunan, 2020). Pasar tradisional didirikan untuk mendukung kesejahteraan masyarakat lokal. Pasar ini memiliki peran penting dalam perputaran roda perekonomian rakyat dan menjadi denyut nadi perekonomian dari rakyat (Kalsum \& Purnomo, 2019). 
Di zaman sekarang, pasar dikategorikan menjadi dua jenis yaitu pasar tradisional dan pasar modern (Aliyah, 2020). Perbedaan di antara pasar tradisional dan pasar modern adalah kondisi pasar tradisional yang kumuh, jorok, dan kurang layak (Arianty, 2014). Pasar tradisional memiliki sarana dan prasarana yang kurang baik, suasana yang kurang nyaman, kurang modal, dan mahal pada beberapa produk tertentu. Pasar modern memiliki sarana dan prasarana yang lebih baik terutama dalam aspek dari kenyamanan, keamanan, kebersihan, kelengkapan fasilitas pendukung, dan sistem pengelolaan yang modern (Bintoro, 2010). Munculnya pilihan baru ini membuat masyarakat beralih dari pasar tradisional secara berangsur (Arianty, 2014).

Menurut Tambunan (2020), kelemahan dari pasar tradisional dalam bersaing dengan pasar modern adalah kurangnya manajemen dan kurangnya kemampuan untuk beradaptasi dengan perkembangan teknologi informasi pada masa kini. Pemerintah berusaha membersihkan kota dari PKL (Pedagang Kaki Lima), menempatkan mereka ke kios-kios pasar tradisional, serta mengharuskan mereka membayar harga sewa (Malano, 2011). Namun, posisi kios di tempat yang sepi membuat pedagang merugi (Malano, 2011). Oleh karena itu, penelitian ini menganalisis permasalahan manajemen harga sewa di pasar tradisional.

Penelitian terdahulu telah menemukan adanya hubungan antara konfigurasi ruang dan pergerakan manusia (Aydoğan \& Salgamcioglu, 2017). Temuan ini dapat diartikan bahwa susunan toko di pasar tradisional mempengaruhi pergerakan pengunjung. Penelitian lainnya, menemukan adanya pengaruh pergerakan pengunjung terhadap penjualan (Kong dan Kim, 2012). Toko dengan posisi yang ramai pergerakan pengunjung memiliki penjualan yang lebih laris. Fakta-fakta ini telah disadari oleh manajemen mall dan digunakan sebagai sistem penetapan harga sewa (Deb, 2013). Penelitian ini berhipotesis bahwa penetapan harga sewa di pasar tradisional tidak pertimbangan posisi toko nya. Oleh karena itu, penelitian ini menganalisis hubungan konfigurasi ruang dan harga sewa.

Beberapa penelitian terdahulu menilai konfigurasi ruang pasar tradisional dengan menggunakan metode space syntax. Sebagai contoh: Alhamdani \& Sari (2019) menggunakan space syntax untuk mengevaluasi konfigurasi ruang pasar tradisional dari aspek perilaku pengunjung; Nurhalimah \& Astuti (2020) menggunakan space syntax untuk mengetahui penyebaran pengunjung di pasar tradisional, dan; Rosid \& Nareswari (2020) menggunakan space syntax untuk mencari faktor yang mempengaruhi pergerakan pengunjung di pasar tradisional. Namun, belum ada penelitian yang menggunakan space syntax untuk dikorelasikan dengan harga sewa. Space syntax merupakan metode analisis spasial yang mampu memprediksi pergerakan manusia dalam suatu ruang dengan aspek perilakunya (Bafna, 2003). Dalam metode ini, ruang dinilai dari seberapa mudah aksesnya dan seberapa jauh ruang dari akses masuk (Barada, 2013).

Penelitian ini menganalisis konfigurasi ruang Pasar Tradisional Bestari Bintan Center. Pasar ini merupakan salah satu pasar di Kota Tanjung Pinang. Pasar tradisional Bestari Bintan Center adalah tempat utama kegiatan perekonomian masyarakat Kota Tanjung Pinang dengan luas lantai sekitar 4.500 meter persegi. Pasar tradisional Bestari Bintan Center terletak di lokasi perdagangan dan cukup dekat dengan daerah pemukiman. Lokasi Pasar Tradisional Bestari Bintan Center merupakan lokasi yang cukup ramai dan strategis. Tujuan penelitian ini adalah untuk menemukan hubungan antara harga sewa dengan konfigurasi ruang dari pasar tradisional. Harapan dari penelitian ini adalah agar sebagai justifikasi kurangnya manajemen di pasar tradisional.

\section{KAJIAN PUSTAKA}

\section{Pasar Tradisional}

Di Indonesia dengan besarnya angka kehidupan, membuat kondisi sosial ekonomi semakin meningkat. Peningkatan kondisi 
sosial ekonomi ini dapat dilihat dari pekerjaan, pendidikan kesehatan dan pemenuhan kebutuhan hidup. Di dalam pemenuhan kebutuhan hidup manusia terdapat berbagai jenis kebutuhan manusia. Untuk memenuhi kebutuhan tersebut, masyarakat memerlukan suatu wadah yang biasa disebut pasar.

Pada umumnya dapat dikatakan bahwa pasar tradisional adalah suatu tempat dimana terjadi transaksi di antara penjual dan pembeli untuk pemenuhan barang yang dikehendaki dan secara pelaksanaannya masih secara tradisional yaitu terdapat interaksi langsung antara penjual dan pembeli. Pasar tradisional itu sendiri merupakan tempat dimana terjadinya suatu bentuk kegiatan pendistribusian barangbarang dari tangan produsen hingga menuju ke konsumen. Kegiatan seperti ini terbentuk karena adanya permintaan pemenuhan kebutuhan barang untuk masyarakat. Pasar tradisional ini sendiri merupakan suatu tempat untuk masyarakat memenuhi kebutuhan dan keperluan kehidupan sehariharinya. Menurut Belshaw (Suprapto, 1988 dalam Nurhayati, 2017) Pasar merupakan suatu kawasan yang memiliki berbagai unsur seperti unsur sosial, ekonomis, kebudayaan, politis, dan sebagainya, tempat pembeli dan penjual saling bertemu untuk melakukan suatu transaksi.

Jika dilihat dari dua sisi, pasar dapat dilihat dari segi sosial ekonomi dan segi fisik (Ibrahim, 1979 dalam Nurhayati, 2017). Dari segi sosial ekonomis, pasar dibedakan pengertiannya secara kultural, administrasi dan fungsi. Ketiga pengertian tersebut antara lain :

a. Secara kultural, pasar merupakan suatu kawasan tempat terjadinya suatu aktivitas perdagangan eceran dari berbagai jenis barang. Barang-barang yang dijual tidak diperiksa dahulu tentang ketersediaannya secara resmi atau tidak oleh pemerintah.

b. Secara administrasi, pasar diartikan sebagai tempat kegiatan transaksi jual beli barang secara eceran yang dibedakan atas pasar resmi dan tidak resmi. Resmi dan tidak resminya pasar ditentukan oleh tercatatnya pasar tersebut dalam surat keputusan pemerintah. Pasar tidak resmi tidak memiliki surat ini. Namun, pasar ini diakui keberadaannya.

c. Secara fungsi, pasar adalah suatu kawasan perbelanjaan kebutuhan pokok maupun sekunder yang diperlukan oleh masyarakat luas, tempat bekerja (berdagang) dan tempat pedagang mendapatkan penghasilan, serta sebagai suatu fasilitas di kota yang memberikan pendapatan bagi pemerintahan kota.

Jika dilihat dari segi fisik, pasar dapat dikatakan sebagai suatu area yang mana di dalamnya terdapat pemusatan beberapa pedagang tetap dan sementara yang terdapat dalam suatu ruangan terbuka maupun tertutup atau di suatu sisi jalan. Selanjutnya pedagang - pedagang umumnya menempati bangunan dengan kondisi temporer, semi permanen, dan juga permanen.

Menurut Lubis di dalam Nurhayati (2017), yang dapat dikatakan sebagai suatu pasar tradisional adalah pasar dengan rupa bangunannya yang sederhana, dengan suasana dari kawasan tersebut kurang menyenangkan (ruang usaha yang kecil, kotor, dan pencahayaan yang kurang). Barang yang dijual merupakan suatu barang kebutuhan sehari - hari dengan mutu yang kurang baik, dengan harga yang murah, dn untuk membeli terdapat transaksi tawar menawar di dalamnya. Hampir seluruh pedagang merupakan masyarakat ekonomi lemah dan sistem berdagangnya tidak profesional.

\section{Konfigurasi Ruang}

Ruang merupakan perpaduan 3 dimensi dari panjang, lebar dan tinggi yang dapat mewadahi aktivitas. Kompleksitas aktivitas manusia membutuhkan ruang yang diatur atau diurut sedemikian rupa dalam suatu konfigurasi yang memudahkan aktivitas sehingga efektif dan efisien (Nurhalimah \& Astuti, 2020). Dalam teorinya Hillier (2007), dikatakan bahwa suatu ruang terbentuk dari 
koneksi antara suatu ruang dengan ruangruang lain sebagai tempat berkegiatannya pengguna. Dalam hal ini, Hillier (2007) melihat suatu konektivitas antara suatu ruang dan manusia sebagai pengguna atau menetap di dalam suatu ruang. Hillier dan Hanson (2003) tidak merujuk pada konektivitas tersebut sebagai konfigurasi ruang secara bersamaan. Setiap hubungan mempunyai bentuk interpretasi perilaku dalam menanggapi bentuk maupun fungsi dari ruang. Sistem dari ruang tersusun dari dua komponen utama antara lain layout dan konfigurasi. Secara fisik, sistem ruang ini termanifestasi dalam morfologi. Kedua komponen ini sangat krusial karena komponen ini menjadi penentu pergerakan manusia dan dapat digunakan sebagai parameter dalam pengembangan Kawasan.

\section{Space Syntax}

Space syntax adalah metode untuk mendeskripsikan dan menganalisis hubungan antara ruang perkotaan dan bangunan. Arsitek biasanya menyebut hubungan ini sebagai tata letak. Space syntax laboratory bahwa space syntax itu sendiri adalah suatu metode untuk menganalisis konfigurasi ruang, yang mana konfigurasi ruang tersebut merupakan aspek yang penting di dalam hubungan manusia baik di dalam skala bangunan maupun skala kota. Space syntax paling baik dijelaskan sebagai program penelitian yang menyelidiki hubungan antara masyarakat manusia dan ruang dari perspektif teori umum tentang struktur ruang yang dihuni dalam segala bentuknya yang beragam: bangunan, permukiman, kota, atau bahkan lanskap. Tujuan dari space syntax adalah mengembangkan pemahaman mengenai kinerja ruang yang berkaitan dengan pergerakan pengguna ruang dalam sebuah konfigurasi ruang (Barada. 2013). Hillier dan Hanson (1984) menjelaskan bahwa space syntax analisis digunakan untuk menganalisis hubungan spasial antara ruang yang berdekatan dan mengidentifikasi konektivitas ruang secara langsung maupun tidak langsung. Metode analisis space syntax digunakan untuk menentukan bagaimana tata letak berfungsi. Analisis space syntax digunakan untuk menghasilkan kombinasi dari grafik visibilitas, polygon visibilitas, konektivitas ruang.

Untuk penjelasan teori dan metode space syntax yang digunakan di dalam penelitian ini, akan dijelaskan tipe analisis perhitungan yang dan jenis mapping yang digunakan.

\section{Analisis Perhitungan Dalam Space Syntax}

Dalam space syntax, terdapat beberapa jenis analisis dasar. Analisis-analisis ini dapat digunakan pada mapping di DepthmapX. Terdapat 3 jenis analisis dasar yaitu connectivity, integration, intelligibility, dan step depth namun yang hanya digunakan dalam penelitian yaitu analisis integration dan step depth.

\section{A. Integration}

Integration adalah ukuran global dari posisi relatif setiap ruang ke ruang lainnya dalam suatu konfigurasi ruang. Integration disebut properti global karena perhitungan nilai integration tidak hanya melibatkan berbagai ruang yang terkoneksi secara langsung, tetapi juga ruang-ruang lain yang terkoneksi tidak secara langsung (Siregar, 2014). Menurut Netzell (2013), nilai integration dipercaya sebagai potensi determinan dari pola pergerakan manusia dan sebagai tingkat kognitif manusia dalam persepsi dan berproses dalam ruang. Dalam perhitungan ini, ruang-ruang yang tidak dapat diobservasi dari titik pengamatan juga dilibatkan. Penilaian integration dari suatu ruang akan melibatkan seluruh ruang lainnya dalam suatu konfigurasi ruang (Hillier, 2007). Analisis integration juga dapat dimanfaatkan untuk mempelajari kedekatan ruang-ruang dalam suatu konfigurasi ruang. Ruang dengan nilai integration yang tinggi dapat diinterpretasikan sebagai ruang yang mudah dicapai dari setiap ruang dalam konfigurasi ruang. Demikian sebaliknya, ruang dengan nilai integration yang rendah akan cenderung lebih terpisah dari ruang-ruang lain dalam konfigurasi ruang.

Untuk mengetahui bagaimana kondisi konfigurasi ruang dapat dilihat melalui 
pengukuran integration ruang. Menurut Hillier dan Hanson di dalam Siregar (2014) suatu ruang yang memiliki nilai integration tinggi (kedalaman / depth yang rendah) dapat dianggap memiliki interaksi yang terkoneksi dengan baik ke ruang pengamatan maka semakin tinggi pula nilai integration ruang tersebut, sebaliknya semakin buruknya interaksi dari suatu ruang ke ruang lainnya maka semakin rendah pula nilai integration ruang tersebut.

Pada gambar 1 dapat dilihat di ruang $\mathrm{X}$ sebagai ruang pengamatan memiliki nilai integration yang relatif lebih tinggi daripada ruang-ruang lainnya, dikarenakan ruang $\mathrm{X}$ terhubung secara langsung dengan banyak ruang-ruang lain yang berada di sekitarnya.

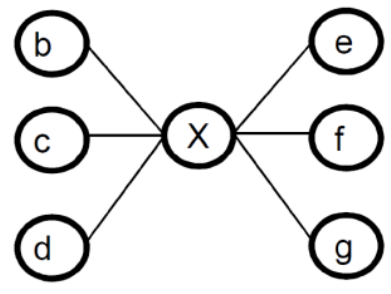

Sumber : (Siregar, 2014).

Gambar 1: Ruang pengamatan dengan nilai integration yang tinggi

Pada Gambar 2, dapat dilihat di ruang a dan ruang $\mathrm{c}$ sebagai ruang pengamatan memiliki nilai integration yang relatif lebih rendah sebab memiliki lebih banyak ruang antara ruang - ruang lainnya. Berbeda dengan ruang $\mathrm{b}$ dan $\mathrm{c}$ yang memiliki lebih sedikit ruang antaranya,

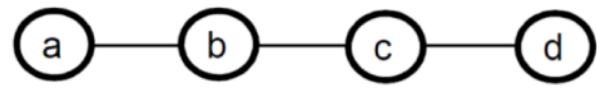

Sumber : (Siregar, 2014).

Gambar 2: Ruang pengamatan dengan nilai integration yang rendah

\section{B. Step Depth}

Analisis step depth pada space syntax merupakan analisis yang digunakan untuk mengukur langkah yang diperlukan dalam pencapaian suatu ruang. Step depth juga menerapkan konsep jarak di dalamnya diukur dalam setiap langkah. Menurut Siregar
(2014), satu nilai step depth berarti jarak antara ruang terhubung secara langsung sedangkan, jika nilai antar ruang di atas 1 step depth berarti hubungan ruang tidak langsung berarti ada perantara di antaranya. Pada gambar 3, dapat dilihat jarak di antara a-b, bc dan sebaliknya memiliki nilai step depth 1 karena pencapaiannya yang langsung sedangkan jarak a-c memiliki nilai step depth 2 karena harus melewati ruang $b$.

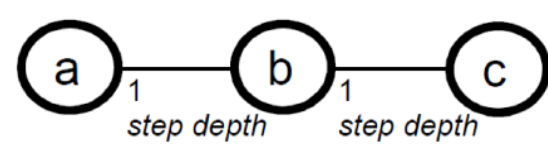

Sumber : (Siregar, 2014)

Gambar 3: Nilai Step Depth Pada Konfigurasi Ruang

\section{Visibility graph analysis (Spatial map)}

Visibility graph analysis menganalisis sejauh mana titik mana pun dalam jaringan spasial terlihat dari titik lain. Jika titik tidak terlihat secara langsung, ukuran grafik dari matriks titik dapat dihitung untuk menguji berapa banyak titik intervensi yang diperlukan untuk satu titik agar dapat melihat titik lainnya (Dessykkas \& Duxbury, 2001). Visibility graph analysis pertama kali digunakan oleh Braaksma dalam studi bandara untuk mengidentifikasi hubungan visual dan spasial antara berbagai fasilitas (Turner, 2001). Visibility graph analysis menunjukkan titik mana saja pada koneksi spatial ke koneksi lainnya. pada titik yang tidak terlihat secara langsung, grafik pengukuran dari nilai matrix bisa di kalkulasikan untuk melihat berapa nilai yang diperlukan dari satu titik untuk melihat titik lainnya (Dessykkas \& Duxbury, 2001).

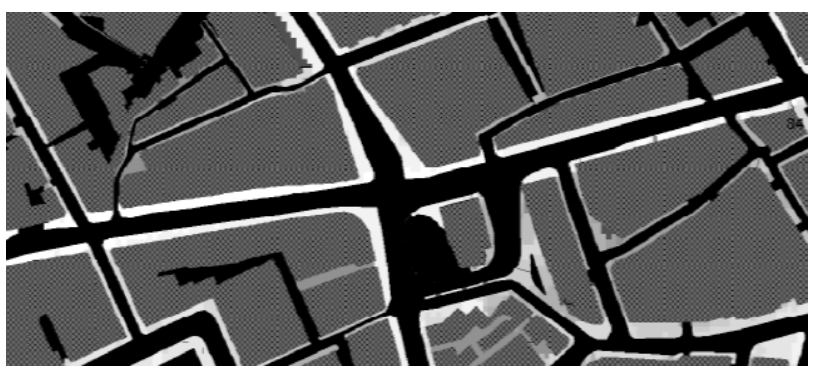

Sumber : (desyllas et al, 2001)

Gambar 4: Contoh Visibility graph analysis 


\section{METODE}

Lokasi yang dipilih sebagai objek penelitian merupakan pasar yang berada di kota Tanjung Pinang. Pasar ini dipilih karena berada di pusat kota dan banyak diminati oleh masyarakat sekitar. Pasar Tradisional Bestari Bintan Center adalah salah satu pasar utama yang paling sering dikunjungi masyarakat Kota Tanjung Pinang. Pasar tradisional Bestari Bintan Center ini merupakan pasar tertutup dengan toko bersekat dinding dan memiliki pintu masing-masing. Pasar ini berlokasi di Kelurahan Air Raja, Kecamatan Tanjung Pinang Timur. Ukuran luas lantai bangunan ini adalah sekitar $4.500 \mathrm{~m}^{2}$. Kawasan pasar ini merupakan lokasi perdagangan dan cukup dekat dengan daerah pemukiman sehingga lokasi tempat pasar tradisional Bintan Center merupakan lokasi yang cukup ramai dan strategis.

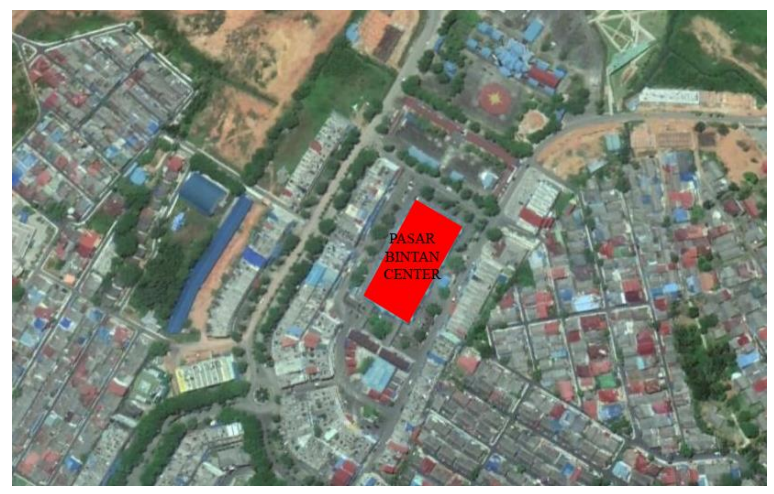

Sumber : (Google Earth, 2021)

Gambar 5: Lokasi Pasar Bintan Center

Tahapan-tahapan penelitian ini dimulai dari mencari isu dan permasalahan untuk menjadi acuan penelitian, menentukan rumusan masalah dan tujuan penelitian. melakukan studi literatur tentang space syntax, mendapatkan data yang diperlukan seperti data denah dan data rental price, melakukan analisis space syntax, dan melakukan korelasi antara data dan hasil analisa. Dalam pengumpulan data - data yang diperlukan di dalam penelitian ini dilakukan dengan teknik observasi, wawancara dan komparasi literatur. Untuk mendapatkan data denah pada pasar penulis turun langsung dan mengobservasi pasar untuk mendapatkan dimensi dari pasar tersebut. Untuk mendapatkan data harga sewa, penulis melakukan wawancara terhadap penyewa tenant - tenant yang berada di pasar. Untuk mendapatkan data - data pendukung dalam pengerjaan space syntax penulis melakukan komparasi literatur dari berbagai sumber yang di dapat. Pada penelitian ini dalam menganalisis data menggunakan pendekatan campuran yang terdiri dari dua jenis penelitian yaitu explanatory yang mana pendekatan ini mengumpulkan data dari penelitian kuantitatif lalu kualitatif di dua fase dalam satu studi. Pendekatan campuran ini digunakan pada penelitian dengan melakukan perbandingan antara data yang didapat dengan metode dasar penelitian kualitatif dengan hasil analisis menggunakan space syntax dengan menggunakan DepthmapX yang akan di korelasikan secara statistik.

\section{HASIL DAN PEMBAHASAN}

\section{Gambaran Umum Pasar Tradisional Bintan Center}

Pasar Tradisional Bintan Center adalah sebuah pasar 1 lantai dengan luas lantainya sebesar 3430,3 $\mathrm{m}^{2}$ dengan luas GLA nya sebesar 1927,2 $\mathrm{m}^{2}$ dan ruang sirkulasinya sebesar 1503,1 $\mathrm{m}^{2}$. Menurut Kamawijaya (2019) dengan luas lantai di antara 2787$9290 \mathrm{~m}^{2}$ pasar ini dikategorikan sebagai Neighborhood Centre (Pusat Perbelanjaan Lokal). Tingkat okupansi dari pasar ini mencapai $89 \%$ dari total luas area komersial (GLA atau Gross Leasable Area) dan 11\% tidak tersewa (vacant). Menurut Guimares (2018) Pusat perbelanjaan dengan tingkat kekosongan $10 \%$ hingga 39,9\% adalah pusat perbelanjaan yang dikategorikan struggling atau biasa disebut pusat perbelanjaan yang sedang mengalami kesulitan. 


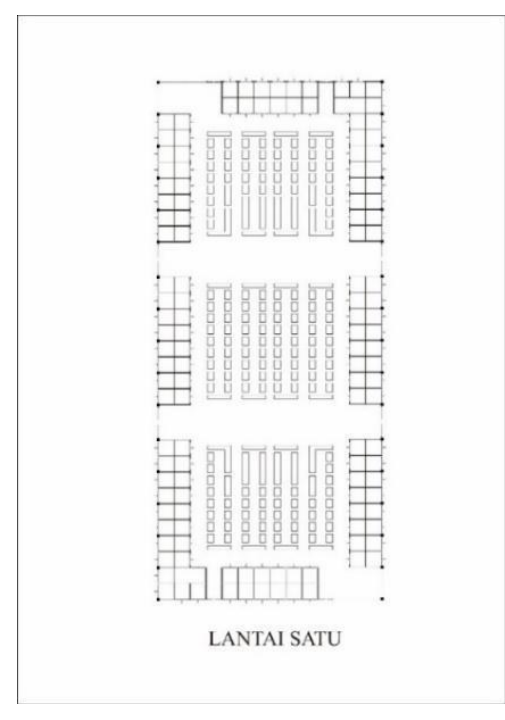

Sumber : (Penulis, 2021)

Gambar 6: Denah Pasar Bintan Center

Ruang sirkulasi pada pasar tradisional Bintan Center memiliki bentuk seperti grid. Menurut Ardella (2021), sirkulasi grid terdiri atas 2 jalur yang sejajar namun berpotongan dan berkembang ke segala arah dan tidak memiliki titik pusat menciptakan ruangan berbentuk persegi maupun persegi panjang. Denah berpola grid sirkulasi di dalam bangunan mencakup seluruh tenant di dalam dan semua meja jualan, sedangkan sirkulasi di luar bangunan merupakan sirkulasi linear berbentuk kotak. Menurut Rahmadani dkk. (2017), pola sirkulasi grid adalah pola sirkulasi yang paling efektif pada pasar tradisional karena dalam penggunaanya lebih efisien dalam membagi retailnya dan memudahkan alur sirkulasi pada saat darurat. Total unit retail di pasar tradisional Bintan Center adalah 302 unit. Unit yang terdapat di dalam bangunan adalah unit meja jual yang terdapat 196 unit dan tenant sebanyak 106 unit. Pada unit meja, semua unit beroperasi sedangkan pada unit tenant terdapat dari 106 unit meja yang ada terdapat 31 tenant yang tidak beroperasi.

Di dalam pasar tradisional Bintan Center terdapat pusat attraction di dalamnya atau yang biasa disebut anchor (magnet). Anchor (magnet) sendiri merupakan sesuatu yang memiliki daya tarik pengunjung yang sangat besar, oleh karena itu, perletakan dari anchor (magnet) ini akan sangat mempengaruhi keberhasilan dari suatu tempat usaha.
Perletakan anchor berkaitan juga dengan komposisi perletakan retail dari seluruh bangunan. Komposisi anchor yang baik dibutuhkan agar sirkulasi menyebar ke seluruh tempat perbelanjaan. Pada pasar tradisional Bintan Center Pusat attraction atau magnet yang ada di dalam bangunan berupa retail meja - meja jualan yang umumnya menjual bahan - bahan pokok yang menjadi tujuan utama masyarakat mengunjungi pasar tersebut seperti daging, sayur dan juga bumbu - bumbu dapur.

\section{Analisis Data}

Di dalam penelitian ini untuk menganalisis data yang sudah terkumpul dapat digunakan jenis analisis integration yang menggunakan space syntax dan analisis step depth dengan space syntax. Hasil analisis dari integration dari space syntax akan dikorelasikan dengan data harga sewa di pasar tradisional Bintan Center untuk melihat apakah ada korelasinya antara nilai integration atau step depth dengan harga sewa di pasar tersebut.

\section{A. Analisis Integration}

Analisis integration visual graph analysis (spatial map) menunjukkan pencapaian di bangunan dan sekitarnya. Dapat dilihat di dalam bangunan terdapat nilai integrasi yang cukup rendah di dalamnya namun karena pusat attractionnya cukup tinggi sehingga area tersebut banyak dilalui oleh pengunjung. Terdapat satu permasalahan pada area diatas denah, walaupun area itu menunjukkan nilai integration yang cukup tinggi namun karena cukup jauh dari entrance dan tidak memiliki variasi dalam berjualan sehingga area tersebut sepi dikunjungi. Di dalam bangunan terdapat pusat hubungan antar sirkulasi di dalam bangunan dan jika dilihat dari analisis integration pada bangunan pasar tradisional tersebut, area tersebut memiliki nilai integration yang paling besar yang terdapat di dalam bangunan.

Terdapat pengecualian suatu fenomena di dalam bangunan, walaupun di dalam bangunan memiliki nilai integration yang 
rendah tetapi karena di dalam bangunan memiliki magnet yang tinggi dia antar tokonya, sehingga terjadi hubungan timbal balik antara semua toko - toko di dalam karena terdapat arus bolak balik antar sirkulasi di dalam bangunan yang membentuk efek ping - pong. Menurut Syoufa dan Hapsari di dalam Andi dkk. (2020), efek ping - pong yaitu terciptanya kontinuitas pergerakan pengunjung seluruh retail toko terjelajahi dan tidak ada area mati.

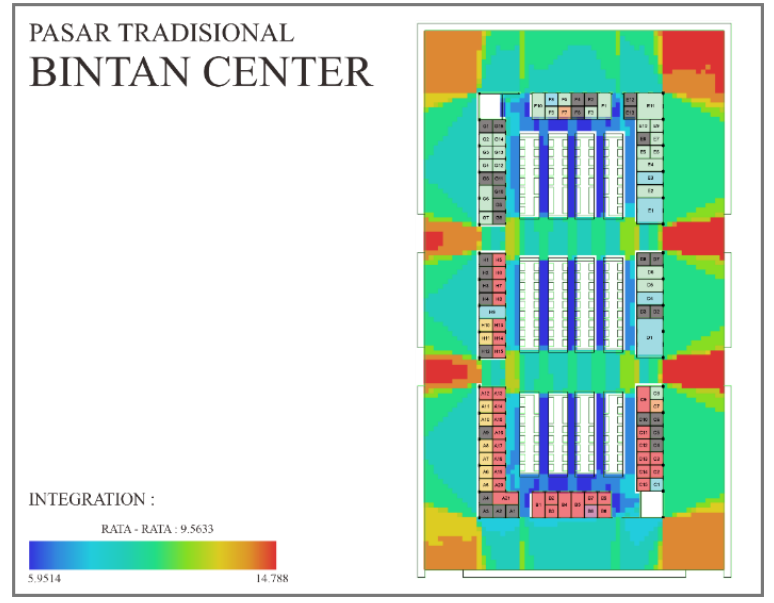

Sumber : (Penulis, 2021)

Gambar 7: Analisis integration spatial map pasar Bintan Center

\section{A. Analisis Step Depth}

Dapat dilihat pada dalam bangunan pasar tradisional Bintan Center terdapat nilai step depth yang tinggi di dalamnya sehingga secara pencapaiannya cukup jauh, namun karena di dalam bangunan pusat attractionnya cukup tinggi sehingga area tersebut banyak dilalui oleh pengunjung. Di dalam bangunan terdapat juga beberapa area dengan nilai step depth yang rendah. Hal ini berarti area tersebut cukup mudah untuk diakses sehingga area tersebut menjadi pusat sirkulasi di dalam bangunan itu sendiri.

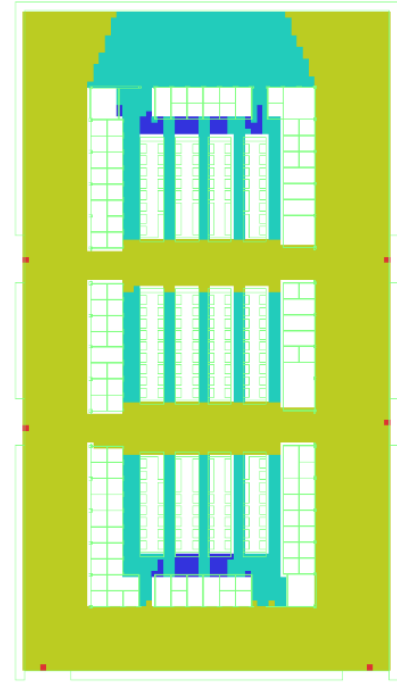

Sumber : (Penulis, 2021)

Gambar 8: Analisis Step Depth pasar Bintan Center

\section{Korelasi Data dan Analisis}

Di dalam penelitian ini korelasi dilakukan dengan menggunakan tiga variabel. Variabel pertama yaitu data harga sewa tenant yang didapat dari observasi lapangan, variabel kedua yaitu nilai yang didapatkan dari hasil analisis integration yang didapatkan menggunakan space syntax, dan variabel ketiga yaitu nilai yang didapatkan dari hasil analisis step depth menggunakan space syntax. Korelasi antara data dan analisis dilakukan pada penelitian ini untuk melihat apakah data yang di dapat di lapangan dan hasil analisis integration memiliki hubungan positif ataupun negatif dan juga bisa di dalam korelasi ini tidak memiliki hubungan sama sekali.

\section{A. Korelasi Data dan Analisis Integration}

Setelah membandingkan data harga sewa tenant dan nilai integration yang di dapat dari analisis space syntax dari pasar ditemukan nilai korelasi yang sangat rendah, temuan mengatakan tenant diberi harga variasi bukan karena tempat yang strategis ataupun tempat yang bagus. Dengan korelasi sebesar $-9,65 \%$ sehingga bisa dikatakan tidak ada hubungannya antara rental price dan nilai integration. harga di tenant bervariasi bukan karena perletakan dan zonasi dari tenant tersebut tetapi karena adanya faktor - faktor lain di dalam penyewaan tenant-tenant yang 
berada di lokasi sehingga harga yang sewa tenant menjadi sangat bervariasi.

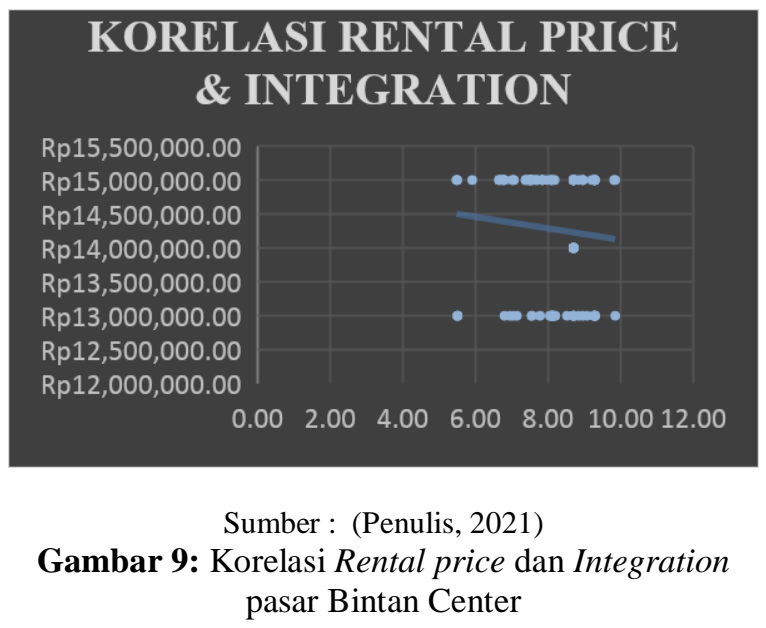

\section{B. Korelasi Data dan Analisis Step Depth}

Setelah membandingkan harga sewa tenant dan nilai step depth yang didapat pada Analisis space syntax, ditemukan nilai korelasi yang sangat rendah sebesar 7,412\% sehingga bisa dikatakan bahwa antara harga sewa dan nilai step depth tidak berhubungan.

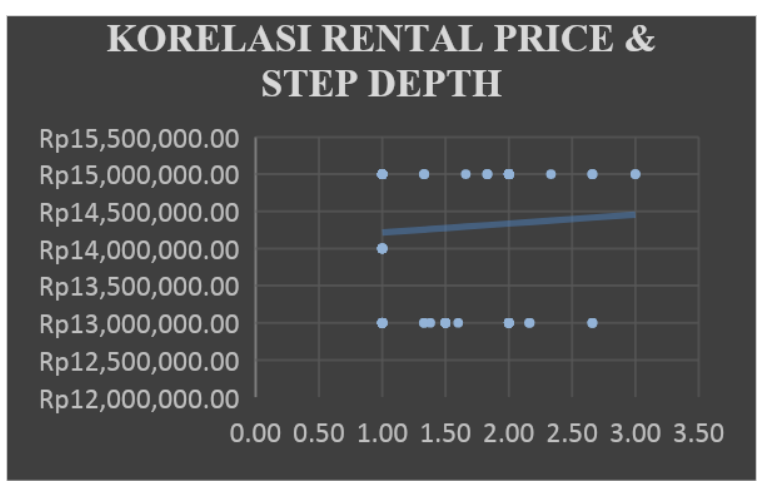

Sumber : (Penulis, 2021)

Gambar 10: Korelasi Rental price dan Step Depth pasar Bintan Center

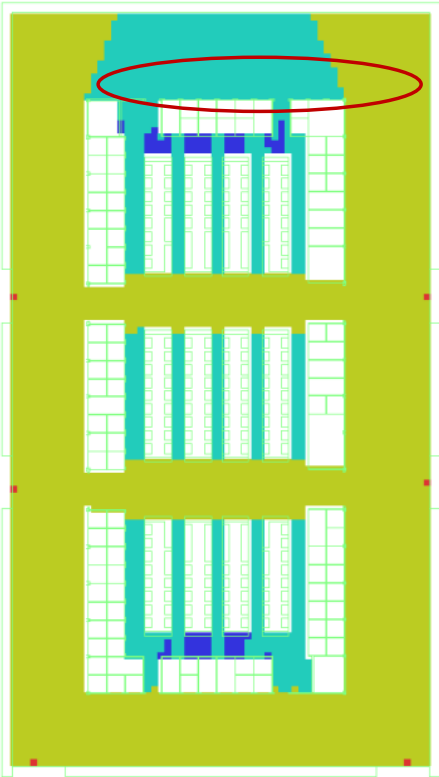

Sumber : (Penulis, 2021)

Gambar 11: Analisis Step Depth pasar Bintan Center

Jika dilihat dari analisis step depth di area atas pada site plan, area tersebut memiliki nilai step depth yang lebih rendah dari pada yang lain, dan secara observasi dapat dilihat pada tenant dan meja yang berada di area tersebut cukup sepi. Walaupun tidak ada korelasi dengan harga dan integration tetapi ditemukan bahwa terdapat strategi yang tidak strategis. Jadi secara visual step depth dan observasi lapangan ditemukan ada tenant - tenant yang tidak memiliki variasi dalam berjualan karena secara observasi jenis barang yang dijual pada area yang sepi ada juga yang menjualnya di area yang ramai sehingga area tersebut lebih sepi pengunjungnya pada pasar tersebut.

Nilai sewa dan kedekatan dengan entrance tidak memiliki korelasi sehingga tenant yang dekat maupun yang jauh memiliki harga yang tidak beraturan. Bahkan terdapat tenant yang memiliki harga yang lebih sama walaupun lebih jauh. Kekosongan di kawasan terjadi karena terdapat harga sewa di kawasan yang tidak beraturan serta hanya terdapat sisa lokasi yang tidak strategis pada kawasan itu sendiri. 


\section{KESIMPULAN}

Penelitian dilakukan untuk mendapatkan korelasi konfigurasi ruang dan data harga sewa. Dari analisis Space syntax dalam analisis integration dan analisis step depth ditemukan terdapat area di dalam pasar yang memiliki nilai integration yang rendah dan nilai step depth yang tinggi namun karena pusat attraction di dalam pasar cukup tinggi sehingga area di dalam bangunan pasar cukup ramai dilewati pengunjung. Dari data analisis space syntax dan data harga sewa, ditemukannya nilai korelasi yang sangat rendah sehingga dapat dikatakan bahwa analisis space syntax dan data harga sewa sama sekali tidak berkorelasi. Nilai korelasi yang didapatkan dari analisis integration dengan data harga sewa sebesar -9,65\% sedangkan nilai korelasi dari analisis step depth dengan data harga sewa sebesar $7,41 \%$.

\section{DAFTAR PUSTAKA}

Alhamdani, M. R., \& Sari, D. P. (2019). Performance Evaluation of Pontianak Kapuas Indah Market from Architecture and Behaviour Aspect. Journal of Architectural Research and Education, 1(2), 107. https://doi.org/10.17509/jare.v1i2.22 301

Aliyah, I. (2020). Pasar Tradisional: Kebertahanan Pasar Dalam Konstelasi Kota. Medan: Yayasan Kita Menulis.

Andi, A., Zain, Z., \& Andi, U. F. (2020). Studi Konfigurasi Ruang Mall (Studi Kasus: Matahari Mall Dan Ayani Megamall

Di Pontianak). Arsitektura, 18(2), 265276.

Ardella, T. R. (2021). Penerapan Pola Sirkulasi Penumpang Terhadap Kemudahan Mobilitas Penumpang Di Terminal Penumpang Bandar Udara Sukabumi. Jurnal Penelitian dan Karya Ilmiah Arsitektur Usakti, 18(01), 14-20.
Arianty, N. (2014). Analisis Perbedaan Pasar Modern Dan Pasar Tradisional Ditinjau Dari Strategi Tata Letak (Lay Out) Dan Kualitas Pelayanan Untuk Meningkatkan Posisi Tawar Pasar Tradisional. Jurnal Ilmiah Manajemen Dan Bisnis, 13(1). 18-29

Aydogan, H., \& Salgamcioglu, M. E. (2017). Architectural Morphology and User Behavior Relationship in Shopping Malls: A Comparative Case Study On Forum Shopping Centers inIstanbul Through Syntactic Analysis. Proceedings 11th International Space Syntax Symposium, 11, 408:1-408:21.

Bafna, S. (2003). Space syntax: A Brief Introduction To Its Logic And Analytical Techniques. Environment And Behavior, 35(1), 17-29.

Barada, W. P. (2013). Analisis Space syntax Rumah Susun Berbasis Gang Kampung. Simposium Nasional RAPI, 13(1), 58-63.

Bintoro, R. W. (2010). Aspek Hukum Zonasi Pasar Tradisional Dan Pasar Modern. Jurnal Dinamika Hukum, 10(3), 349-363.

Deb, S. (2013). The Spatial Economic rationale for Optimum Rent, Area and positioning of Spaces in Planned Shopping Centres. Pacific Business Review International, 5(10), 95-102.

Desyllas, J., \& Duxbury, E. (2001, May). Axial Maps And Visibility graph analysis . Proceedings, $3 r d$ International Space syntax Symposium 27(1), 21-13.

Guimaraes, P. P. C., (2018). The Resilience of Shopping Centres: An Analysis of Retail Resilience Strategies in Lisbon. Portugal. Moravian Geographical Report, 26(3), 160-172.

Halim, C., \& Herlambang, S. (2020). Penataan Ulang Pasar Tradisional Muara Karang. Jurnal Sains, 
Teknologi, Urban, Perancangan, Arsitektur (Stupa), 2(1), 521-532.

Hillier, B. \& Hanson, J., 2003. The Social Logic Of Space. Cambridge: Cambridge University Press.

Hillier, B. (2007). Space Is The Machine: A Configurational Theory of Architecture. Space syntax.

Hillier, B., \& Hanson, J. (1984). The Social Logic Of Space. Cambridge, Uk: Cambridge University Press.

Kalsum, E., \& Purnomo, Y. (2019). Pola Pertumbuhan Pasar Rakyat Di Kota Pontianak. Langkau Betang: Jurnal Arsitektur, 6(2), 136-153.

Kamawijaya, M. H. (2019). TA: PLACE PALASARI SPACE (Doctoral dissertation, Intitut Teknologi Nasional).

Kong, E. M., \& Kim, Y. O. (2012). Development of Spatial Index Based on Visual Analysis to Predict Sales. Proceedings 8th International Space Syntax Symposium, 8, 76:1-76:13.

Malano, H. (2013). Selamatkan Pasar Tradisional. Jakarta: Gramedia Pustaka Utama.

Netzell, O. (2013). The effect of accessibility on retail rents: Testing integration value as a measure of geographic location. Journal of Property Research, 30(1), 1-23. https://doi.org/10.1080/09599916.20 12.713974

Nurhalimah, D., \& Astuti, D. W. (2020). Analisis Hubungan Konfigurasi Ruang Dengan Penyebaran Pengunjung Pasar Klewer Menggunakan Space syntax. Sinektika: Jurnal Arsitektur, 17(1), 13-20.

Nurhayati, S. T., \& Ir Marsudi, M. T. (2017). Kajian Penataan Ruang Pada Kios Atau Ruko Lantai Dua Pasar
Tradisional (Studi Kasus Pasar Mawar Kota Pontianak). Jurnal Teknik Sipil, 17(1).1-16

Rahmadani, S. J. D. K., Sufianto, H., \& Utami, S. (2017). Tata Ruang Pasar Tradisional terhadap Kerentana Kebakaran Studi Kasus Pasar Tekstil Klewer. Jurnal Mahasiswa Jurusan Arsitektur, 5(1).

Rosid, M., \& Nareswari, A. (2020). Hubungan Konfigurasi Ruang Terhadap Tingkat Pergerakan Pengunjung di dalam Pasar Beringharjo. Journal of Architectural Design and Development, 1(1), 27. https://doi.org/10.37253/jad.v1i1.711

Sarwoko, E. (2008). Dampak Keberadaan Pasar Modern Terhadap Kinerja Pedagang Pasar Tradisional Di Wilayah Kabupaten Malang. Jurnal Ekonomi Modernisasi, 4(2), 97-115.

Siregar, J. P. (2014). Metodologi Dasar Space syntax Dalam Analisis Konfigurasi Ruang (Modul Space syntax 1). Malang: Jurusan Perencanaan Wilayah Dan KotaUniversitas Brawijaya.

Syarifuddin, D. (2018). Pasar Tradisional Dalam Perspektif Nilai Daya Tarik Wisata. Jurnal Manajemen Resort dan Leisure, 15(1), 19-32.

Tambunan, T. (2020). Pasar Tradisional dan Peran UMKM. Bogor: IPB Press.

Turner, A. (2001). Depthmap: a program to perform visibility graph analysis. Proceedings of the 3rd International Symposium on Space Syntax, 3, 3112. 
Bidang Lingkungan Binaan dan Rekayasa 